\title{
茶䓵種
}

農林省茶業試験場栽培部茶樹第 2 研究室

\section{Tea Varieties}

By 2nd Laboratory of Tea Plant, Tea Agronomy Division, NRIT

農 林 省 登 録

\begin{tabular}{|c|c|c|c|c|}
\hline 登録番号 & 品 種 名 & 旧 系 統 名 & 両＼cjkstart親＼cjkstart名（来 歴） & $\begin{array}{l}\text { 育 成 年 } \\
\text { (登録) }\end{array}$ \\
\hline 茶農林 1 号 & ベにほまれ & 国茶C 8 号 & $\begin{array}{l}\text { インド（カルカッタ）から罦入したもの } \\
\text { の实生中から選抜したもの }\end{array}$ & 昭和28年 \\
\hline " 2 号 & あさつゆ & " U14号 & 宇治種の实生中から選拔したもの & 28年 \\
\hline " 3 号 & み よ し & " U15号 & " & 28年 \\
\hline " 4 号 & たるみどり & " U17号 & " & 28年 \\
\hline " 5 号 & さやまみどり & 埼玉 1 号 & " & 28年. \\
\hline " 6 号 & やら゙きた & 薮 北 & 静岡県在来種の央生中から選技したもの & 28年 \\
\hline " 7 号 & まきのはらわせ & 牧之原早生 & 静岡県在来種の㬰生中から選㧨したもの & 28年 \\
\hline / 8 号 & $こ や に L$ & 小屋 西 & 宇治種の奏生園から選抜したもの & 28年 \\
\hline " 9 号 & ろ<3 5 & 六 郎 & 在来種から選抜したもの & 28年 \\
\hline " 10 号 & やまとみどり & 奈良59号 & 奈良県在来種の夹生中から選抜したもの & 288年 \\
\hline " 11 号 & たかち瓜 & 棠㥓 9 号 & 在来実生園から選抜したもの & 28年 \\
\hline "12号 & いん ぞ & 鹿印雑 2 号 & インド雑種の実生園から選抜したるの & 28年 \\
\hline " 13 号 & はつもみじ & 鹿アッサム交配 1 号 & $\mathrm{Ai} 2 \times \mathrm{NkaO} 5$ & 28年 \\
\hline " 14 号 & ベにたちわせ & 16 昂 & Ai $26 \times$ Nka $O 1$ & 28 号 \\
\hline
\end{tabular}


品種一覧表

\begin{tabular}{|c|c|}
\hline 性 & 育 成 場 兹 \\
\hline $\begin{array}{l}\text { 晚生種で樹姿中間，樹勢中，葉はだ円形で大きく，濃緑色，再生力大であるが，芽数が少い欠 } \\
\text { 点がある。紅茶として品質優良，特に水色，味が濃厚である。 }\end{array}$ & 茶試 金 谷 \\
\hline $\begin{array}{l}\text { 中生種で樹姿中間，樹勢中，葉は辰た円形で濃緑色，緑茶特に煎茶として品質優秀で天然玉露 } \\
\text { の名がある。 }\end{array}$ & " \\
\hline $\begin{array}{l}\text { 中生種で樹姿開張，樹勢中，葉は長だ円形で緑色，収量は中，結実性大で種子の遺伝的純度が } \\
\text { 高い。煎茶として品質良好である。 }\end{array}$ & " \\
\hline $\begin{array}{l}\text { 中生種で樹姿中間，樹勢極強，葉はだ円形で緑色である。耐寒性が強く，収量が多いが，耐病 } \\
\text { 性（炭そ病）に弱い欠点がある。蒸製玉緑茶として品質優良である。 }\end{array}$ & " \\
\hline $\begin{array}{l}\text { 中生種で樹姿直立，樹勢強，葉怆円形で大きく，濃緑色，耐寒霜性特に強く，耐病性，耐旱 } \\
\text { 性も強い。収量も多く，煎茶として品質優良である。 }\end{array}$ & 埼玉県茶試 \\
\hline $\begin{array}{l}\text { 中生種で樹姿直立，樹勢極強，葉は長だ円形で大きく，耐寒性も相当強いが，炭そ病に弱い欠 } \\
\text { 点がある。憵茶として品質極めて優良である。 }\end{array}$ & 静岡県茶試 \\
\hline $\begin{array}{l}\text { 極早生種で樹姿開張，樹勢中，耐寒性及び耐病性強く，3倍体で不稔性である。槊茶として品 } \\
\text { 質良好である。 }\end{array}$ & $"$ \\
\hline $\begin{array}{l}\text { 中生種であるが摘採期はやや早く，樹姿直立，樹势強，集はだ円形で大きく，奻芽はやや黄緑 } \\
\text { 色であるが，煎茶として品質良好である。 }\end{array}$ & " \\
\hline $\begin{array}{l}\text { 中生種で樹姿中間，樹勢強，葉はた円形で大きいが，牙数が少く幼芽は異緑色である。煎茶と } \\
\text { して品質良好である。 }\end{array}$ & " \\
\hline $\begin{array}{l}\text { 晚生種で樹姿直立，樹勢中，葉は長だ円形で濃緑色，耐寒性特に強く，善芽密で収量は中。結 } \\
\text { 実性が高く，遺伝的純度も高い。煎茶として品質優良である。 }\end{array}$ & $\begin{array}{l}\text { 奈良県農試茶業 } \\
\text { 分場 }\end{array}$ \\
\hline $\begin{array}{l}\text { 中生種で樹姿直立，樹勢やや強，葉は大゙円形で大きく，緑色，耐病性強く，再生力大である。 } \\
\text { 奶芽は淡緑で光沢あり，葉肉厚く，かまいり製玉緑茶として品質優良である。 }\end{array}$ & $\begin{array}{l}\text { 宮崎粽総農試茶 } \\
\text { 鄴支場 }\end{array}$ \\
\hline 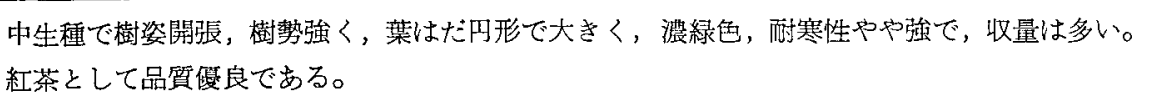 & 毞児島県茶試 \\
\hline $\begin{array}{l}\text { 中生種で樹姿犆立，樹勢極めて強く，葉は長だ円形で特に大きく，淡緑色，タンニン含量はな } \\
\text { はだ多い。収量が極めて多く，紅茶として品質良好で，味が強い。 }\end{array}$ & " \\
\hline $\begin{array}{l}\text { 極早生種で樹姿直立，樹勢強，葉は長だ円形，極大で，淡緑色である。タンニン含量が多い。 } \\
\text { 耐病性強く，再生力大。紅茶として品筫侲良で，温和な味とアッサム系香気を有する。 }\end{array}$ & " \\
\hline
\end{tabular}


茶業研究報告

\begin{tabular}{|c|c|c|c|c|}
\hline 登録番号 & 品 種 名 & 旧 系 統 名 & 両 親 名 （来 歴） & $\begin{array}{l}\text { 䘚成年 } \\
\text { (登録) }\end{array}$ \\
\hline 茶農林15号 & 离吕积 & 鹿アッサム交配 132 号 & Ai $21 \times$ Nka O 3 & 昭和28年 \\
\hline " 16 号 & なっみどり & 国茶 S 41 号 & 静岡県在来種の実生園から選抜したもの & 29年. \\
\hline " 17 号 & や光卧 & 八重穂 & $\begin{array}{l}\text { 静岡景在来種“八重穂”から選抜したも } \\
\text { の }\end{array}$ & 29年: \\
\hline " 18 号 & あさぎり & 京研 113 号 & 京都府在来種の実生園から選抜したもの & 29年 \\
\hline "19年 & きょ5みどり & " 172 焈 & " & 29年 \\
\hline 20 号 & はつみどり & 鹿緑原 5 号 & $\begin{array}{l}\text { 三重県より取り寄せた実生中から選抜し } \\
\text { たもの }\end{array}$ & 29年. \\
\hline ” 21 号 & ベにか怙り & 鹿アッサム交配 8 号 & $\mathrm{Ai} 21 \times \mathrm{NkaO} 3$ & 29 득 \\
\hline " 22 号 & ベにふじ & X 13 号 & ベに海ま机×C 19 & 35年: \\
\hline " 23 号 & ひめみどり & 福 15 号 & 福岡県在来種の実生囷から選抜したもの & 35年 \\
\hline " 24 号 & ฟず み & At 5371 & ベに棌まれの実生中から選抜したもの & 35年 \\
\hline " 25 号 & さっおべに & NA 113 & Nka O $3 \times \mathrm{Ai} 18$ & 35华 \\
\hline " 26 号 & おくむさし & $22-131$ & さやまみどりメやぬとみどり & 37年 \\
\hline " 27 号 & やまなみ & $\mathrm{Ch}-5342$ & $\begin{array}{l}\text { 中国（湖北省）から導入したものの後代 } \\
\text { 実生中から選拔したもの }\end{array}$ & 40年. \\
\hline " 28 号 & ベにひかり & 茶支 $\mathrm{F}_{1}$-ANC 1144 & ベにかおり $\times$ Cn 1 & 44年. \\
\hline " 29 号 & $5 ん$ か & A 15 & たかちほ $\times F_{1}-9-4-48$ & 45年 \\
\hline " 30 号 & かなやみどり & 茶本 $\mathrm{F}_{1}-\mathrm{NN} 13$ & S 6 ×やぶきた & 45年 \\
\hline " 31 号 & さやまか扮り & $\mathrm{G}_{1} 5613$ & やぶきたの自然交雑实生から選抜したも & 46年: \\
\hline " 32 号 & おくみぞり & 茶本 $\mathrm{F}_{1}-\mathrm{NN} 29$ & やぶきたメ静岡在来16号 & 49年 \\
\hline
\end{tabular}

注：Ai はインド・アッサム地方の自生種を道入したもの。

Cは中国から導入したもの。 


\begin{tabular}{|c|c|}
\hline 要 & 育 成 堄 所 \\
\hline $\begin{array}{l}\text { 中生種で樹姿中間，樹勢強く，葉はだ円形で大きく，濃緑色，タンニン含量が多い。耐病性強 } \\
\text { く, 収量が多い。紅茶として品質優良，水色鮮紅色で中国系の清香が高い。 }\end{array}$ & 鹿児島県茶試 \\
\hline 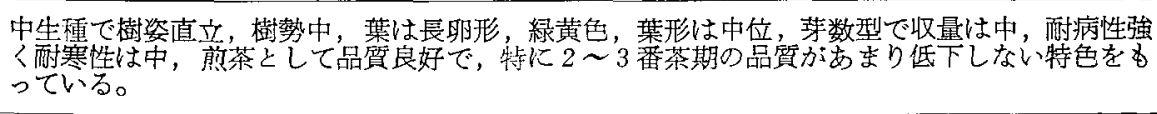 & 茶試 金 谷 \\
\hline 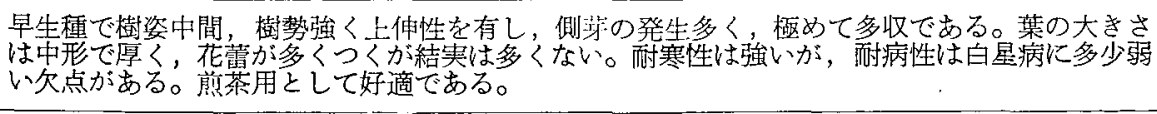 & 静 岡监茶試 \\
\hline 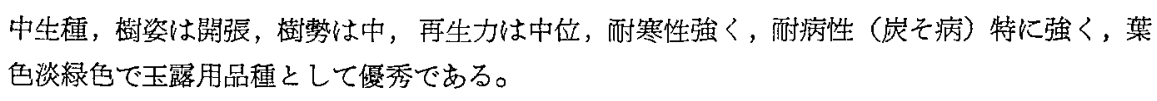 & 京都府茶研 \\
\hline $\begin{array}{l}\text { 中生種で樹勢は中，樹姿直立，葉はだ円形，濃緑色で，耐寒性は強い。玉露用でてん茶として } \\
\text { も品質優秀で，特に色沢滋味が秀れている。 }\end{array}$ & " \\
\hline 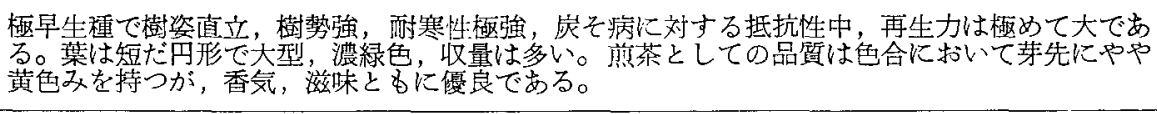 & 鹿児島県茶試 \\
\hline 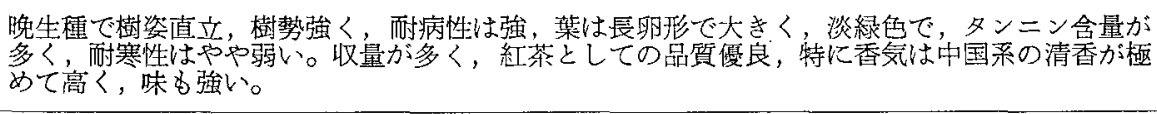 & $"$ \\
\hline $\begin{array}{l}\text { 中生種で樹姿中閒，樹勢強く，一般特性はべに注玉れに似ているが芽数か多く収量が多い。紅 } \\
\text { 茶として品質優良である。 }\end{array}$ & 茶試 金 谷 \\
\hline $\begin{array}{l}\text { 中生種で樹姿中閒，樹勢中，葉はだ円形で小葉に属し，濃緑色，耐寒性，耐病性強く，玉露用 } \\
\text { 品種として優良である。 }\end{array}$ & 九 州 掔 試 \\
\hline $\begin{array}{l}\text { 中生種で樹姿直立，樹勢極めて強く，葉はだ円形で大きく，さ光た緑色 } \\
\text { いが胴枯性病害には強く，多収である。かまいり製玉露茶として品質良 }\end{array}$ & " \\
\hline
\end{tabular}

中生種で樹姿中間，樹势強く，葉は大。紅茶としてアッサム系の優雅な芳香を持ち品碩良好で ある。

麼罗島県茶試

晚生種で樹姿直立，樹勢強く，葉はだ円形で濃緑色，耐寒性，耐病性強く，煎茶として芳香高 く品質良好である。

中生種て樹姿直立，樹樊極めて強く，葉はた円形で淡緑色，耐寒性，耐病性強く，収量は椠定 し，著しく多収。かまいり製玉緑茶として品質良好である。

埼玉県茶試

晚生種で，樹姿中間，樹勢強，集はだ円形淡緑色，耐寒性強，再生力大，多収，紅茶として良 筫である。

中生種で，樹姿中間，樹势強，葉はだ円形濃緑色，耐寒・耐病性強，多収，かまいり茶として 品質良好である。

中晚生種で，樹姿中間，樹势強，葉はだ円形濃緑色，耐寒性強，再生力大，多収，聮荼として 品筫良好である。摘採期㧍そく，やぶきたと組合せるとよい。

やぶたより2，3日早い中生種で，樹姿は中問，樹勢強い。成葉は長だ円形で大きい。耐寒 泩（青祜，赤枯）が強い。收量はやぶきたと同程度で多い。紊茶として内質は香気が強く良好 である。

晚生種で樹姿中間，樹勢が強い。成葉はやぶきたより小さいだ円形で緑色を呈する。牙立ちが よく，芽数型に属する。多収で，耐寒性はやぶきたと同程度に強い。焎茶として外観が緑色で 形すよく，内質はやぶきた程度である。摘探期括えく，やぶきた・かなやみどりと組合せると よい。

日本種茶園から取り寄せたもの。

亳崎県総合農試 茶营支場

茶試枕崎

窝崎䝿総合農試 茶菜支場

茶試 金 谷

埼玉祡茶試

茶試 金 谷 
県で育成された

\begin{tabular}{|c|c|c|c|c|c|}
\hline 県 名 & 品 種 名 & 茶種 & 旧系統名 & 来 & $\begin{array}{l}\text { 育成年 } \\
\text { (登録) }\end{array}$ \\
\hline 茨 & ベKつくば & 紅 & & 真壁町上谷貝の在来茶園よりの選抜 & 33年 \\
\hline 静 & するがわせ & 槊 & 7109 & やぶきたの自然実生 & 37年 \\
\hline " & 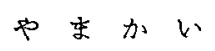 & " & 7166 & $"$ & 42年 \\
\hline " & $<5 d わ$ & " & 7111 & " & " \\
\hline " & ふじみどり & " & 7224 & 不 明 & 37年 \\
\hline$"$ & 㭱亏りょく & " & 4018 & 多田采印雑の実生 & 31年 \\
\hline$"$ & からべに & 紅 & 5031 & 湖北省種の実生 & " \\
\hline " & たたににも & " & 4008 & 多田系印雑の垁生 & 33年 \\
\hline 京 & 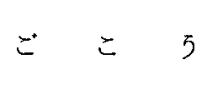 & $\begin{array}{l}\text { てん } \\
\text { 玉 }\end{array}$ & 京研 166 号 & 京都府在来種の実生園から選拔 & 28年 \\
\hline " & $5 し ゙ ひ か り$ & " & 京研 170 号 & " & " \\
\hline " & あ さひ & " & 平野11号 & " & $"$ \\
\hline " & 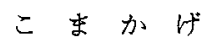 & " & 平野 55 号 & " & " \\
\hline " & さみどり & " & 小山69号 & " & $"$ \\
\hline$"$ & 抢ぐらみどり & " & 小山78号 & " & " \\
\hline 鹿 巟 島 & くりたわせ & 煎 & 栗田早生 & $\begin{array}{l}\text { 昭和 } 2 \text { 年静岡県在来種より栗田茂三郎氏 } \\
\text { が選抜 }\end{array}$ & 41年 \\
\hline$"$ & ゆたかみどり* & " & Y 2 & あさつゆの自殖種 & " \\
\hline
\end{tabular}

*: 茶業試験場で育成された系統であるが鹿児島県で溪励品種に採用されているためここに揭げた。 


\section{主 要 品 種 (昭和 50 年 1 月現在)}

\begin{tabular}{|c|c|c|}
\hline 概 & 育 成 場 所 & 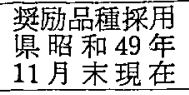 \\
\hline 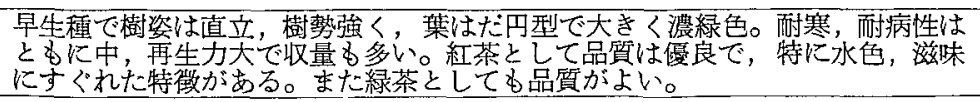 & $\begin{array}{l}\text { 真壁地区曹業 } \\
\text { 改良普及所 }\end{array}$ & \\
\hline 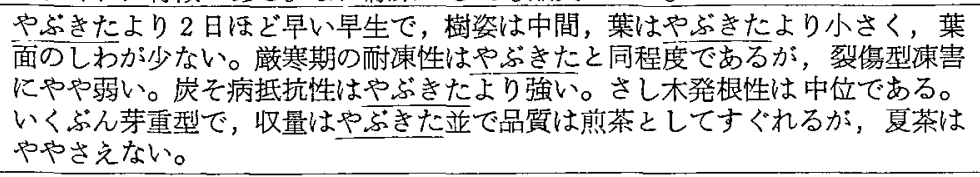 & 静業岡試験埸 & 静 岡, 奈 良 \\
\hline 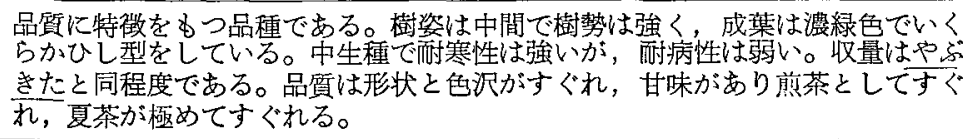 & " & 静 岡, 福 岡 \\
\hline 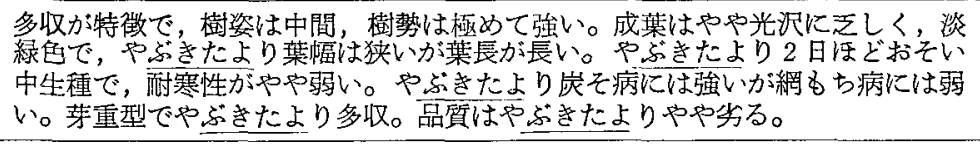 & " & 静 \\
\hline 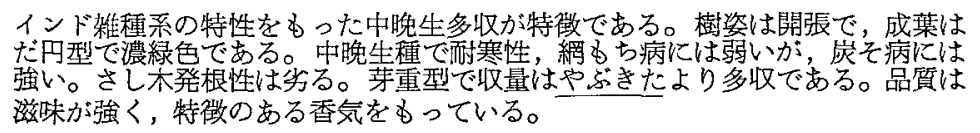 & " & 静 \\
\hline 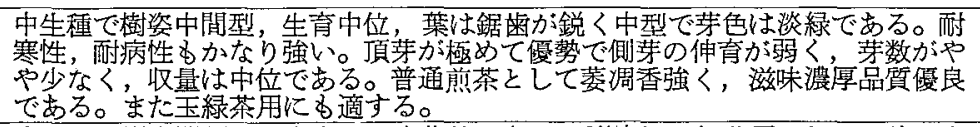 & " & \\
\hline 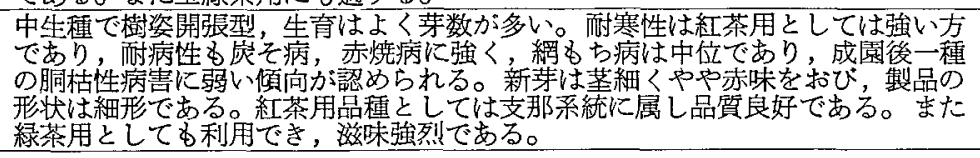 & " & \\
\hline 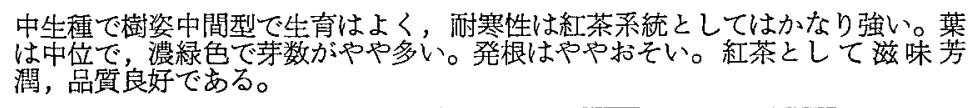 & " & \\
\hline 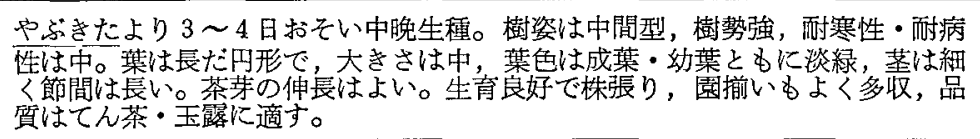 & 京都府茶研 & 京 \\
\hline 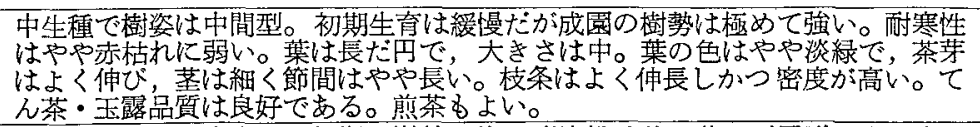 & " & 京 \\
\hline 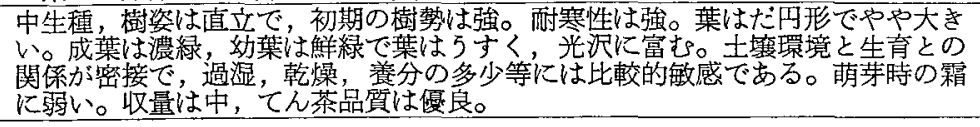 & " & 京 \\
\hline 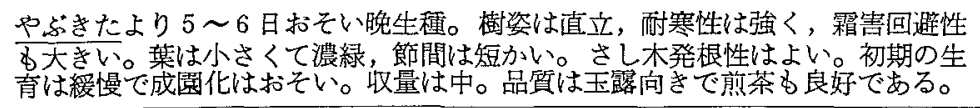 & " & 京 \\
\hline 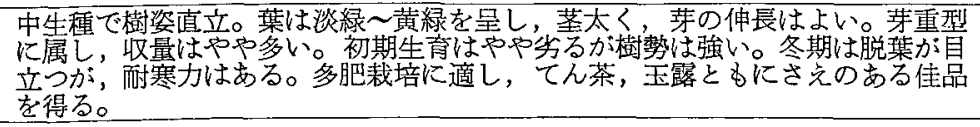 & " & 京 都，福 网 \\
\hline 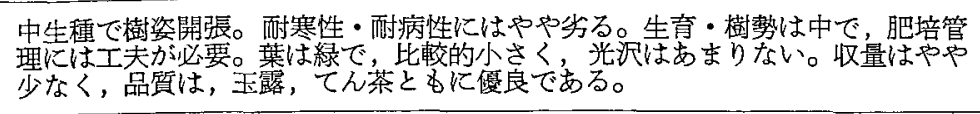 & " & 京 \\
\hline 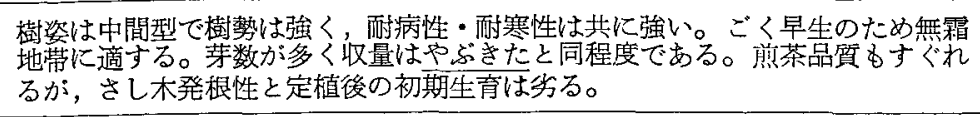 & 鹿児島罧茶試 & 鹿 \\
\hline 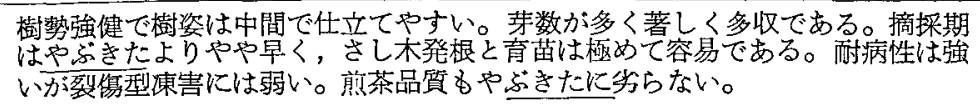 & 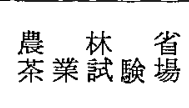 & $\begin{array}{l}\text { 麇児島, 熊本, } \\
\text { 管 }\end{array}$ \\
\hline
\end{tabular}


主要茶産県の奨励品種と主要

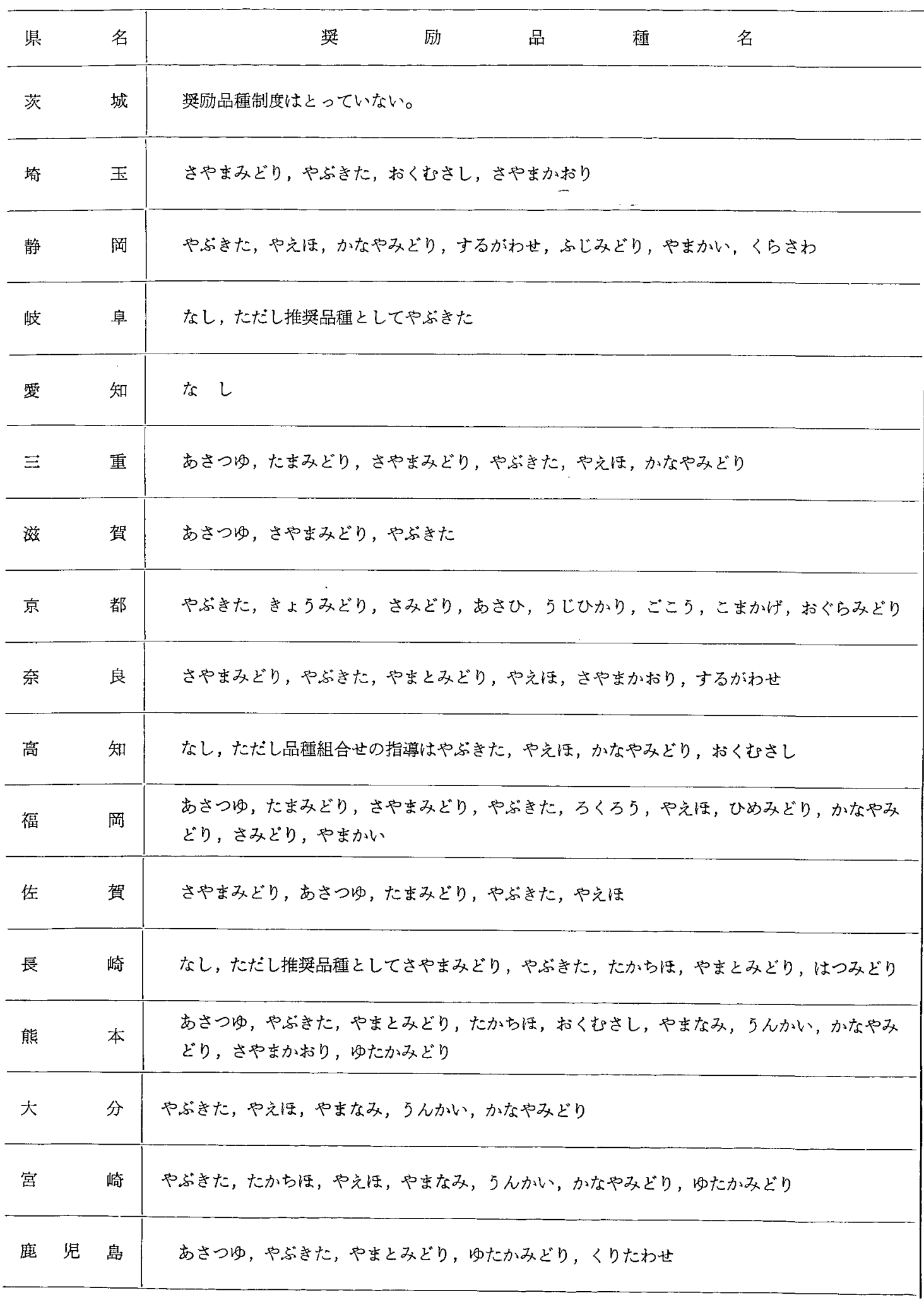

注 1 ：（）は推定。

注 2 ：（）は昭和48年茶統計年報より抜粋。

(May 1, 1975) . 
品種 の栽 培 面 積 (昭和49年11月末現在)

\begin{tabular}{|c|c|c|c|}
\hline 主 要 品 種 の 截 培 面 積 (ha) & $\begin{array}{l}\text { 品種茶園 } \\
\text { 面愤計 } \\
\text { (ha) }\end{array}$ & $\begin{array}{l}\text { 在来茶園 } \\
\text { 面積計 } \\
(\text { ha) }\end{array}$ & $\begin{array}{l}\text { 貣茶園 } \\
\text { 面 } \\
\end{array}$ \\
\hline やぶきた 380 & 380 & 1,090 & 1,470 \\
\hline やぶきた570，さやまみどり50，おくむさし6，さやまか抢り 2 & 628 & $(2,692)$ & $(3,320)$ \\
\hline $\begin{array}{l}\text { やぶきた5982,くらさわ229，するがわせ195，ふじみどり148，やまかい108， } \\
\text { や亮は70，かなやみどり20 }\end{array}$ & 6,752 & $(14,048)$ & $(20,800)$ \\
\hline 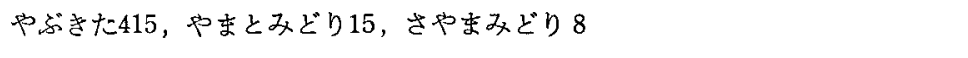 & 438 & (912) & $(1,350)$ \\
\hline やぶきた442，その他（やまとみどり，やまかい） 78 & 520 & 416 & 936 \\
\hline やぶきた1392，あさつ鸟464，たまみどり232 & 2,088 & $(1,812)$ & $(3,900)$ \\
\hline 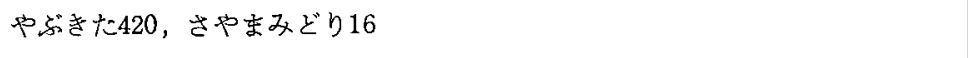 & 436 & 840 & 1,276 \\
\hline 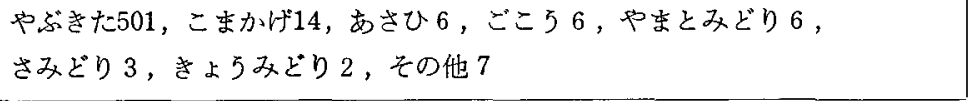 & 545 & 1,026 & 1,571 \\
\hline やぶきた610，やまとみどり25，その他 5 & 640 & 861 & 1,501 \\
\hline 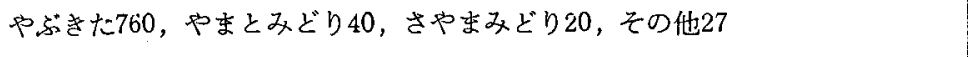 & 847 & 313 & 1,160 \\
\hline やぶきた 550 ，さやまみどり10，その他20 & 580 & (910) & $(1,490)$ \\
\hline やぶきた 451 ，さやまみどり23，おくむさし10，かなやみどり 9，その他26 & 519 & 571 & 1,090 \\
\hline 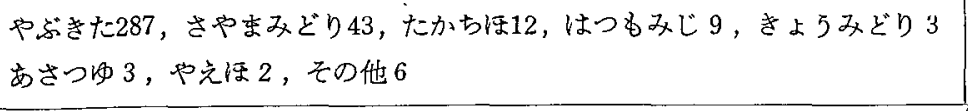 & 365 & (483) & (848) \\
\hline やぶきた1080，やまとみどり38，ざやまみどり26，あさつゆ15，その他76 & 1,235 & 775 & 2,010 \\
\hline 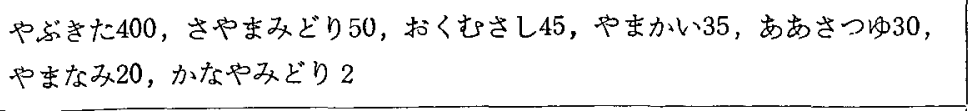 & 582 & (304) & (886) \\
\hline 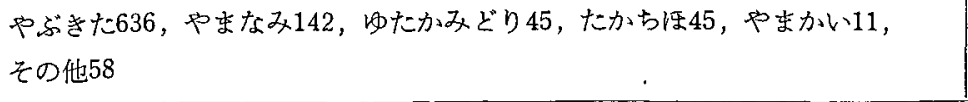 & 937 & 883 & 1,820 \\
\hline 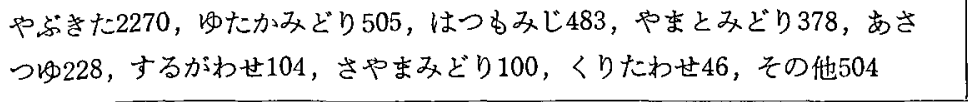 & 4,618 & 2,217 & 6,835 \\
\hline
\end{tabular}

